\title{
Constraints on Private Benefits of Control: Ex Ante Control Mechanisms versus Ex Post Transaction Review
}

by

\author{
Ronald J. Gilson and Alan Schwartz*
}

\begin{abstract}
We ask how to regulate pecuniary private benefit consumption. These benefits can compensate controlling shareholders for monitoring managers and investing effort in implementing projects. Controlling shareholders may consume excessive benefits, however. We argue (a) ex post judicial review of controlled transactions dominates ex ante restrictions on the controlled structures: the latter eliminate efficiencies along with abuses of the controlled company form; (b) controlling shareholders should be permitted to contract with investors over private benefit levels. Both work with better courts. Hence, we recommend creating a European-level corporate court, whose jurisdiction parties can invoke by contract. (JEL: D02, G34, K22)
\end{abstract}

\section{Introduction}

This paper takes as its foundation four central facts. First, control blocks in corporations with public shareholders are pervasive. Only a handful of countries have capital markets that are dominated by companies whose control is in the public float (the evidence is summarized in Gilson, 2006). Second, control blocks do not exist, as the Law and Finance literature (La Porta et al., 1998) would have it, only in consequence of weak corporate governance law. ${ }^{1}$ Control blocks are also pervasive in "good law" jurisdictions such as Sweden, and commonplace in others such as the

* Meyers Professor of Law and Business, Stanford Law School, Stern Professor of Law and Business, Columbia Law School, and European Corporate Governance Institute; Sterling Professor of Law, Yale Law School; Professor, Yale School of Management. Corresponding author: Alan Schwartz. The authors are grateful to Luca Enriques, Guido Ferrarini, and to participants at the Bruges Symposium on Behavorial Theory of Institutions (2012) for comments.

1 The expressed concern is that controlling shareholders are reluctant to yield control because the law would permit the new controlling group to exploit them. 
United States (Gilson, 2006). ${ }^{2}$ These controlling shareholders may exist because they have better techniques for monitoring management (or for better managing the corporation) than the monitoring techniques used in public corporations without a controlling shareholder - for example, independent boards of directors and the market for corporate control (Gilson and Schwartz, 2012; Gilson, 2006; Gilson and Gordon, 2003). Third, in both good and bad law jurisdictions, shareholders often acquire control with "leverage" - the set of techniques that give controlling shareholders voting rights that exceed their cash-flow equity rights. Examples are dual-class common stock structures in which the controlling shareholders hold high-vote stock and public shareholders hold low-vote stock; and pyramids in which shareholders that control the top firm with a majority equity stake control lower firms with only minority equity stakes.

Fourth, recent reforms restrict agents' ability to secure control blocks, especially those that use leverage. Many countries prohibit dual-class common stock structures (Institutional Shareholder Services, Shearman \& Sterling, and the European Corporate Governance Institute, 2007; henceforth ISS, 2007) (dual-class common stock is allowed in only half of the countries surveyed). A report to the European Commission by the High Level Group of Company Law Experts recommended a "proportionality principle," requiring voting rights and equity participation to match ("Report of the High Level Group of Company Law Experts," 2011). This recommendation led the European Commission to initiate a report on the legality and actual use of leveraged control in the European Union (ISS, 2007): the European Commission did not propose regulatory action. Dual-class common stock is also prohibited in Israel, and a recent Israeli government commission recommended severely limiting leveraged control through pyramid structures ("Recommendations of the Committee on Enhancing Competitiveness," 2011). ${ }^{3}$ Even when leveraged control is absent, European Union law nevertheless disadvantages controlling shareholders in public corporations through the mandatory bid rule, that requires a shareholder who crosses a thirty-percent ownership threshold to offer to purchase the shares of all other shareholders at an average of the recent prices that the thirty-percent shareholder paid to acquire its stake ("UK Takeover Panel," 1972, and The European Parliament and the Council of the European Union, 2004). ${ }^{4}$

This actual and proposed regulation is intended to prevent controlling shareholders from consuming private benefits of control ("PBC") - a pecuniary or nonpecuniary gain that a shareholder acquires through use of its controlling position, and which is not shared with public shareholders. A pecuniary private benefit, for

2 In the U.S., roughly six percent (by number, not value) of public corporations have two classes of common stock (Gompers, Ishii, and Metrick, 2010).

3 The authors filed a report on behalf of certain Israeli pyramid groups analyzing the proposed restrictions (available at http://www.mof.gov.il/lists/list26/attachments/ 291/2011-1111.pdf).

4 The mandatory bid rule originated in the City Code (1972) by the UK Takeover Panel (available at http://thetakeoverpanel.org.uk/wu-conten/uploads/2008/12/197202.pdf). It was applied EU wide through the Takeover Directive in 2004. 
example, may accrue to a controller through an interested transaction, in which the controlling shareholder stands on both sides of the deal. On one side is the company he controls; on the other side is a company in which the controller has a larger equity stake. (Atanasov, Black, and Ciccotello, 2011, provide a detailed taxonomy of PBC extraction methods.) A pecuniary PBC exists when the transaction terms unduly favor the entity in which the controlling shareholder has the higher equity stake (Gilson and Gordon, 2003). The treatment of PBC also figure prominently in the literature discussing sales of corporate control. For present purposes, we treat the issue of $\mathrm{PBC}$ in control sales as derivative of the rules governing $\mathrm{PBC}$ in the ongoing operation of the company - i.e., the value of $\mathrm{PBC}$ in the sale of control is just the capitalized value of the PBC generated in the company's operations.

PBC are regulated because they are believed to disadvantage minority shareholders, whose returns fall as the controllers take a disproportionate share of the corporation's profits. On this view, leveraged control is particularly problematic because it facilitates the controlling shareholder's ability to consume PBC, in particular by diverting assets to entities in which the controlling shareholder has greater equity (Claessens et al., 2002; Gompers, Ishii, and Metrick, 2010). ${ }^{5}$ But PBC have virtues as well as vices. They compensate controlling shareholders for the monitoring they provide and the diversification they yield to maintain control. Leveraged control permits controlling shareholders to exploit economies of scale and scope in monitoring and in managerial talents. Leverage also reduces the extent of firm-specific risk the controlling shareholder must bear and for which he otherwise would have to be compensated (for a discussion, see Dammann, 2008).

As premise to discussing regulatory strategies, we note that some balance of the virtues and vices of PBC consumption exists today. To see how, let there be no credible constraints on how much of the public shareholders' investment the controlling shareholder can divert. Then, the controlling shareholder would take everything. On the other hand, there would be nothing to take: investors with rational expectations would not hold equity in controlled companies. Put another way, if the controlling shareholder cannot commit to restrict his consumption of $\mathrm{PBC}$, "why is not the value of minority shares [...] - and, it follows, the number of minority shareholders - zero?" (Gilson, 2007, pp. 634f.). The existence of controlled companies thus implies that their controllers today credibly commit, in some imprecise ways, to some limits on PBC consumption. The relevant question, then, is whether the state should attempt to improve the controlling shareholder/minority shareholder deal or attempt to stamp out PBC consumption altogether.

In general, two regulatory strategies address PBC: ex ante regulatory restrictions that constrain or prohibit leveraged capital structures or more generally restrict the existence of a structure with a controlling shareholder and public-minority shareholders; and ex post judicial review of transactions that a controlling shareholder can

5 In East Asia for example, the level of PBC is increasing in the difference between a controlling shareholder's equity and control (see Claessens et al., 2002). This result also holds in the United States (see Gompers, Ishii, and Metrick, 2010). 
use to extract PBC, but without restricting the adoption of a controlling shareholder structure. Regarding the former, roughly half of European Union countries prohibit dual-class common stock, and others limit the extent of the preferential voting rights the controlling shareholders can hold. Sweden limits the high voting class to 10 times the lower voting class; France limits it to two times (ISS, 2007). A mandatory bid rule operates to constrain the controlling shareholder/public-minority shareholders structure by requiring that a shareholder who obtains a large percentage of voting rights - typically 30 percent - must offer to purchase all minority shares (Enriques, 2000). These restrictions rest on the premise that PBC consumption is altogether bad, so the opportunity of controlling shareholders to consume them (or sell them) should be restricted or eliminated. Because regulatory "slippage" exists, most countries also impose a higher standard of judicial review on transactions that could provide a vehicle for the extraction of PBC (Gompers, Ishii, and Metrick, 2010). ${ }^{6}$ Alternatively, ex post review of interested transactions accepts the possibility that controlling shareholders may add value, and so seeks to assure that the net (of PBC) benefits the controllers create are positive. Gompers, Ishii, and Metrick (2010) provide some empirical support for the proposition that markets efficiently assess the level of the controlling shareholder's private benefit extraction. In their study, dual-class firms do not experience negative abnormal returns over the period. This implies that the price paid to shareholders discounts the level of PBC extraction.

Thus, there is a regulatory continuum between ex ante structural restrictions on control structures and ex post transaction review. Europe and the United States rest at different points along that continuum. European countries rely more heavily on ex ante structural restrictions, ${ }^{7}$ the United States almost entirely forgoes structural reform in favor of ex post judicial review that evaluates particular transactions in which PBC may be extracted. (Pennsylvania, for example, has a mandatory bid rule, enacted to deter hostile tender offers.) The European mandatory bid rules thus protect public shareholders against being frozen into a corporation with a controlling shareholder and therefore risking dilution through the extraction of private benefits. The United States, in contrast, constrains a controlling shareholder from extracting PBC through freezing out public shareholders by subjecting a freezeout transaction to searching judicial scrutiny (Gilson and Gordon, 2003). Similarly, no U.S. state limits the use of dual-class stock. ${ }^{8}$ While the United States does restrict the use of pyramids by taxing inter-company dividends when the recipient company does not own 85 percent of the payer company, dividends are only the most observable way of transferring corporate resources. PBC extracted through inter-company dealings

6 Enriques (2000) surveys European legal regimes concerning director self-dealing.

7 EU member states also limit the terms of the transactions through which controlling shareholders may extract PBC (see Enriques, 2000, and Conac, Enriques, and Gelter, 2007). We stress later, however, the terms of the substantive law are of limited significance in the absence of effective judicial review.

8 U.S. stock exchange rules restrict dual-class common stock in the U.S. only if they are created by changing the rights of existing stock. Companies may issue new classes of limited voting stock - e.g., Google, Zynga, Facebook, and Groupon. 
or other mechanisms are not taxed as dividends, so the inter-company dividend tax is not a complete barrier to a pyramid structure.

The policy question usually asked is whether structural reform or judicial review is the better way to stamp out PBC consumption. We ask a different question here: how should the state maximize the virtues and restrict the vices of PBC consumption? The answer, we argue, is to provide mechanisms through which controlling shareholders can credibly commit to limit PBC consumption to efficient levels - where the gains from better monitoring and management exceed the PBC cost to minority shareholders.

Our analysis proceeds as follows. In section 2, we analyze the tradeoff between ex ante and ex post regulation. We make two points here. First, ex post regulation of PBC consumption can take two forms. (a) The state can retain the mandatory rules that prohibit contracting about levels of PBC consumption. Delaware courts, for example, now use these rules to regulate transactions that implicate $\mathrm{PBC}$ under the entire fairness standard. The efficient consumption of PBC, as just defined, should satisfy the standard. (b) Alternatively, the state could reduce mandatory rules to defaults. This would permit parties to regulate PBC consumption under express contracts between controlling shareholders and shareholder representatives, such as disinterested directors, perhaps with the approval of disinterested shareholders (Delaware General Corporation Law). ${ }^{9}$ Courts then would carefully scrutinize these contracts to ensure that they meet appropriate procedural standards, such as disclosure of relevant facts to the approving body. Second, either ex post regulatory method - direct judicial review or contracting with court review - is preferable to ex ante structural restrictions because structural restrictions, when effective, constrain PBC by restricting the incidence of controlling shareholders. This result is undesirable because controlling shareholders can increase the value of minority shares conditional on the efficient level of PBC consumption, which, in general, is positive (Mahoney, 2012). ${ }^{10}$ In section 3, we examine the institutional infrastructure necessary to support an ex post review approach to constraining private benefits of control. We show that the effectiveness of an ex post standard is increasing in the expertise of the reviewing court because of the reduced likelihood of judicial error (Gilson, Sabel, and Scott, 2012). The lower the error probability, we argue, the larger is the set of efficient projects controlled companies will pursue.

We emphasize that the effectiveness of judicial review - both the quality of the judges and the institutional structure that provides an unbiased outcome within a commercially reasonable period of time - is more important than the details of the

9 Delaware General Corporation Law section 122(17) provides an example of this approach. The section authorizes a corporation by contract or in its charter to alter the application of the corporate opportunity doctrine.

10 Paul Mahoney (2012) provides evidence that pyramids in the U.S. existing before the Pubic Utility Holding Company Act ("PUHCA") prohibited their use in the utility industry managed this balance. The value of both the top-tier company and its controlled subsidiaries increased on news suggesting that the PUHCA would not be enacted and decreased on news favorable to its passage. 
legal standard that a country adopts. Professors Guido Ferrarini and Paolo Giudici make just this point with respect to the Parmalat scandal, which involved large transfers of PBC through interested transactions:

"[...] Italian substantive rules cannot be blamed for what occurred in Parmalat. Indeed, we argue that the existing Italian substantive rules that have been in place during the last decade were sufficient and, somewhat surprisingly, were even stricter than those in the United States. If gatekeepers were undeterred, it is not due to Italian substantive law, but rather the enforcement regime." (Ferrarini and Giudici, 2006, p. 160)

Section 4 asks how to implement an ex post review strategy in countries that lack effective enforcement institutions. To illustrate the question's importance, consider a company that wishes to limit PBC consumption that is incorporated in a country without effective courts as we have defined them. An equilibrium that has "commitment contracts" between the controlling group and outside investors that restrict PBC consumption would violate subgame perfection. After outside investors contribute money to a company, the controlling shareholder has an incentive to exceed a contractual cap because he anticipates the lack of an effective judicial check. As a consequence, equilibria likely would be pooling: well and badly governed companies would face the same inefficiently high cost of capital.

We offer two suggestions for mechanisms that improve the ability of controlling shareholders to credibly commit to efficient levels of PBC. The first, and more modest, proposes that the European Union could facilitate credible commitment by controlling shareholders in countries with weak judicial enforcement by establishing an EU-level commercial court, whose jurisdiction a corporation could opt into through its articles of incorporation or in important contracts. The court would apply the law of the state of incorporation (The Council of the European Union, 2001a,b). ${ }^{11}$ Rather than harmonizing substantive law, this approach would help controlled companies to commit credibly to ceilings on PBC already set out in existing substantive law in the member state of incorporation. The second suggestion is consistent with and extends the first: member states could amend existing, typically mandatory, substantive law in a critical respect: existing legal standards would become default rules, allowing corporations to make explicit tailored commitments with respect to PBC consumption. Section 5 concludes.

\section{The Tradeoff between Ex Ante and Ex Post Regulation}

We begin by setting out how agency costs exist in companies with widely distributed shareholders and professional managers who hold a small portion of the company's cash flow rights, which we call Berle and Means ("B\&M") companies (Berle and

11 One precedent for a voluntary election of EU-level regulation is the European Company Law, which does not displace member-state corporate law, but allows individual companies to opt into EU-level institutions. 
Means, 1932). ${ }^{12}$ How agency costs are addressed in B\&M companies is useful background for analyzing the various legal responses to agency costs in companies that have a controlling shareholder.

\subsection{The Pervasive Potential for Agency Costs}

Agency problems exist whenever shareholders invest in a company they do not control. The benefits that result from the specialization that capital markets make possible - investors in risk bearing and managers in managing - also create the potential for agency costs. Beginning with benefits, public shareholders usually hold diversified stock portfolios. Therefore, they do not bear firm-specific risk, and so need not be paid to bear it. Diversification, that is, reduces capital costs. In turn, the opportunity for an entrepreneur to secure external capital on good terms allows managers to specialize in management: a good manager need not contribute substantial capital to the enterprise. This specialization has allowed the professionalization of management.

Specialization, however, creates the potential for two broad categories of agency cost. First, managers may manage inefficiently (evoking their legal duty of care); second, managers may favor themselves at the expense of minority shareholders (evoking their legal duty of loyalty). Efficient specialization requires that the law effectively address these derelictions. Minority shareholders will not reduce them by monitoring. Because of risk-bearing specialization, noncontrolling shareholders lack both the expertise to monitor the performance of specialized managers and the incentive to do so - their individual holdings are too small to warrant the effort. The minority is rationally passive. A company's cost of capital reflects the agency costs that its structure permits (Jensen and Meckling, 1976). ${ }^{13}$

\subsection{Controlling Agency Costs without a Controlling Shareholder}

B\&M companies address these generic agency problems in a distinctive fashion, whose outline highlights the tradeoff between ex ante and ex post approaches to a controlling shareholder's PBC.

\subsubsection{Lack of Diligence and Poor Performance}

The techniques for protecting minority shareholders should vary with the type of agency cost presented. Ex post judicial review is ill suited to addressing bad management; courts are poor institutions for policing a lack of managerial diligence

12 We refer to a company in which shareholders are widely diversified and the managers have effective control but hold a small fraction of cash flow rights as a Berle and Means company, after the scholars who first characterized this organizational form (see Berle and Means, 1932).

13 Jensen and Meckling (1976) is the canonical account of the role of agency costs in corporate organization. 
or poor manager performance. ${ }^{14}$ Denote a realized firm project as $v$; commonly $v=f(e, \Theta)$, where $e$ is managerial effort and $\Theta$ is a stochastic state variable. Courts seldom can observe either effort or the probability distribution of states against which the company made its effort choice. Put simply, a reviewing court cannot determine, based on a single observation, whether an observed unfavorable outcome was the result of bad luck (managers predicted the right probability distribution but the outcome was unfavorable) or bad judgment (managers predicted the wrong probability distribution and the unfavorable outcome would have been expected if they had gotten it right in the first place). As a result, even jurisdictions with good courts severely restrict judicial inquiry into managerial performance in the absence of a conflict of interest. In the United States, the business judgment rule immunizes most managerial behavior from judicial scrutiny (The American Law Institute, 1994, e.g., section 4.01).

Restricting judicial review of allegedly poor management performance does not leave management insulated from review; rather, markets are a more effective institution for policing managerial performance. Specialized analysts who can evaluate a pattern of events rather than a single occurrence undertake the policing task. Repeated poor performance causes a company's share price to drop and also risks more dramatic responses, such as a proxy fight, a takeover, active shareholder interventions to change corporate policy and, in the worst case, creditor actions that force bankruptcy. Therefore, an effective match between problem and remedy exists regarding managerial lack of diligence or poor performance in B\&M companies. The policing task is assigned to the market rather than to the courts. ${ }^{15}$

\subsubsection{Regulating PBC Consumption: Disloyalty and Interested Transactions}

In contrast to market review of performance issues, legal rules are the primary defense to agency costs that present as disloyalty or self-interested transactions. Interested transactions may have economic value, so the better strategy apparently is to subject them to judicial review rather than prohibition. Statutes and courts create, and courts apply, standards to assess the terms of self-interested transactions. The basic question standards pose is whether the terms of a self-dealing transaction sufficiently resemble the terms that would obtain from arm's-length bargaining in the same transaction type.

An effective court commonly can recover the facts relevant to answering this question. Contract terms and prices are verifiable, market prices for similar transactions may exist, and expert testimony is often useful. Hence, courts can effectively police self-dealing: that is, they can apply the equivalence test. Parties that anticipate effective judicial oversight are induced to conform their ex ante behavior to the law.

14 We use the phrase "managers" to refer both to directors and managers unless otherwise indicated.

15 The compensation contract also responds to poor managerial performance. We abstract from compensation issues here because our focus is on legal institutions. 
In sum, the law matches the agency problems that attend B\&M companies to the most effective responses. Courts police conflicts of interest, and the capital market polices lack of diligence or poor performance.

\subsection{Controlling Agency Costs with a Controlling Shareholder}

\subsubsection{Lack of Diligence and Poor Performance}

The analysis above argued that markets are better than courts at controlling poor managerial performance. Controlling shareholders may be better still (Gilson, 2006; Gilson and Gordon, 2003). A controlling shareholder commonly has the skills, the opportunity and the incentive to monitor manager diligence and performance in the publically held company. Regarding skills, the controlling shareholder usually is himself an industry expert; regarding opportunity, the controlling shareholder participates in the business in an ongoing way; regarding incentives, the controlling shareholder commonly has both nontrivial cash flow rights and the opportunity to divert returns from successful projects to himself, which gives him an incentive to make projects successful.

In comparison to a controlling shareholder, markets are an inexact method of control, even if better than courts. Markets best respond to obviously poor performance, which is observable in cause and extent - when the magnitude of lost value is large and the steps necessary to address poor performance are straightforward. In particular, markets respond late to problems that require deep knowledge of the corporation's business and operations to evaluate; even when poor performance is observable to outsiders, assessing the precise causes and how they can be addressed may not be. Also, the large premiums in takeovers, especially hostile ones, suggest that managerial poor performance must be significant and persistent before markets act.

Controlling shareholders do not suffer from the limited vision outsiders have into the corporation's actual workings. Thus, they are an effective alternative to market policing of the agency cost of managerial shirking and poor performance, behaviors that result from the specialization of management in the modern company. Public shareholders' specialization in risk bearing creates the managerial independence that permits managers both to mismanage as well as to maximize value. A controlling shareholder, including those relying on leveraged control (for example, dual-class common stock and pyramids), can respond effectively to mismanagement, and so may better help the controlled company to realize the gains from professional management at lower agency costs than do markets.

\subsubsection{Disloyal and Self-Interested Transactions}

The existence of a controlling shareholder as a high-powered performance monitor, however, poses a heightened risk of self-dealing. The very scale and scope economies that permit better monitoring also create the potential for greater consumption of $\mathrm{PBC}$. In advanced economies, the law responds to loyalty and self-dealing issues in 
controlled companies in much the same way as it responds to these concerns in the $\mathrm{B} \& \mathrm{M}$ corporation. This is unsurprising, but not entirely satisfactory. The position of management as regards self-dealing in a B\&M corporation with widely distributed shareholders presents an extreme version of the position of a controlling shareholder whose control is leveraged: there exists a very large wedge between B\&M company management's control and its equity.

The analysis of how to address the potential for self-dealing in a controlled company thus partly parallels the analysis of how to address the potential for self-dealing in the B\&M setting. As discussed in the Introduction, a controlling shareholder has an incentive to capture a disproportionate share of the benefits of effective monitoring by diverting resources to entities in which he has a larger equity stake. The use of leveraged control allows capturing economies of scale and scope in monitoring, but at the cost of heightened incentives to self-deal. Interested transactions may have value in this context as well; the legal task is to distinguish the good from the bad. Efficient legal rules and effective judicial enforcement apparently permit the state to realize the agency cost reductions from more effective monitoring by controlling shareholders while constraining excessive self-dealing.

The controlled corporation is more difficult to regulate than the B\&M company, however. In the B\&M company, the task is to permit interested transactions but under terms that replicate arm's-length transactions. In the controlled company context, the task is more complex. The controlling shareholder's incentive to monitor managers and otherwise effectively to implement projects is too low because the shareholder holds less than all of the cash flow rights. Permitting controllers to extract PBC from valuable transactions partly overcomes the disincentive to maximize that diluted cash flow rights create. Requiring self-interested transactions exactly to mimic market transactions, however, could prevent a controlling shareholder from consuming any PBC. As a result, some efficient transactions would not take place. The regulatory task for controlled companies therefore is to permit economically valuable transactions while also permitting appropriate levels of PBS consumption; in other words, to permit PBC to the extent that the benefits to noncontrolling shareholders from better monitoring exceed the costs of PBC. We argue next that contract and legal standards achieve this task better than ex ante prohibitions.

\subsection{The Choice between Ex Ante and Ex Post Regulation in Companies with a Controlling Shareholder}

Conditional on the expertise and effectiveness of the judicial system, it is straightforward to demonstrate the superiority of ex post judicial review. Let the substantive law be that in Delaware, ${ }^{16}$ and further assume that, as is essentially the case in all jurisdictions, the rules governing interested transactions are mandatory; that is, individual corporations cannot alter them. Delaware law subjects interested trans-

16 We often refer to Delaware law because more than half of U.S. public corporations are incorporated in Delaware, and Delaware law influences the law in other states. 
actions - those with the potential to create PBC - to searching judicial review under an entire fairness standard. This standard requires the terms of the interested transaction to fall within a range of reasonableness in relation to those of arm's-length transactions. Courts thus implicitly recognize that some level of PBC consumption is acceptable, but a reasonableness standard is required importantly to constrain their extent.

Rough empirical evidence supports this view of judicial performance. Different measures suggest that the value of controlling shares exceeds that of minority shares in U.S. corporations, but by only a small amount (Nenova, 2003; Dyck and Zingales, 2004). Correspondingly, in the U.S., we observe companies with both widely distributed and controlling shareholder structures. Judicial review, that is, allows different corporate control structures to emerge endogenously. Put another way, $\mathrm{PBC}$ consumption is at levels that support a controlling shareholder structure when it is efficient (Gilson, 2006).

Turning to ex ante structural restrictions, we begin with the familiar justifications for mandatory rules. First, mandatory rules are used to prohibit transactions that create negative externalities. Second, mandatory rules may protect parties who cannot make maximizing choices, either in consequence of cognitive error or an irremediable information deficit. Neither justification applies strongly to the mandatory judicial review just discussed. Controlling shareholders internalize the costs of consuming PBC, capital markets are information rich and the buy side participants - the public shareholders - are sophisticated. ${ }^{17}$

Ex ante structural restrictions on control represent the strongest form of mandatory rule. The restrictions cannot rest on the usual justifications for mandatory rules. Rather, the argument must be that ex post constraints inevitably fail; they result in excessive PBC consumption. The argument here rejects this view. Rather, restricting control structures that present conflicts of interest, as opposed to policing the terms of actual conflicted transactions, lumps efficient and inefficient transactions together, thereby eliminating both.

\section{Contract and Judicial Expertise}

\subsection{Contracting with Standards and Formal Agreements}

We noted above that ex post judicial review can take two forms: (a) The courts' application of a mandatory entire fairness-like standard to interested transactions; (b) The same standard but expressed as a default rule that permits express con-

17 Controlling shareholders bring to market the projects that reflect the privately optimal tradeoff between a controller's payoff through his cash flow rights and his payoff from $\mathrm{PBC}$ consumption. The capital market may prefer a different mix. This reasoning implies that the controllers may not seek external finance for the highest valuing projects (in expectation) in their project portfolios. This externality is hard to regulate because project portfolios, in contrast to actual projects, usually are unobservable by third parties. 
tracting about $\mathrm{PBC}$ consumption. The courts' role in the default rule setting would be to police the contracting process for procedural fairness (including approval requirements) and disclosure, and to enforce the PBC contract adopted.

We argue here that the current mandatory regime should be demoted to a regime of PBC defaults. As premise, realize that controlled firms that offer stock to the public credibly commit to abide by the caps conditional on (and to the extent of) the effectiveness of judicial enforcement. Hence, the claim we made in section 2 actually holds that credible commitment to particular PBC levels through the application of a judicially imposed standard is preferable to ex ante prohibitions.

We support this argument further with three assumptions: (a) there can be efficiency gains as well as agency costs when a controlling shareholder consumes pecuniary private benefits; (b) capital market investors are sophisticated, and so can evaluate commercial transactions that are proposed to them; (c) outside investors contribute money to controlled companies only on terms acceptable to the investors. These assumptions together imply that expert application of legal standards limiting PBC consumption increases efficiency. Assumption (c) holds that a controlling shareholder who needs external finance would engage in interested transactions only if the transactions generated expected returns that equal or exceed the investors' opportunity cost of funds - that is, there are net gains from PBC consumption. Assumption (a) implies that terms attractive to outside investors will maximize the efficiency gains and minimize the agency costs associated with the controlling shareholder's resort to the equity market. Assumption (b), in turn, implies that potential shareholders of controlled companies can evaluate the transactions that controlling shareholders propose.

On the three assumptions, the ex post application of legal standards capping PBC has some of the virtues that explicit contracting generally has. To begin, if PBC consumption is challenged, the controlled company will inform the court about the nature of the challenged transactions, which will inform the court's view of what is reasonable. Because commercial parties can choose and implement maximizing strategies, judicial review under standards partly reflects the virtues of private ordering. Further, parties internalize the costs and benefits of transactions. Here, the controlling shareholder who is selling stock pays in the form of a lower equity price for the later opportunity to consume PBC; hence, it has an incentive to cap such private benefits at efficient levels.

The three assumptions that generate these conclusions are weak. Assumptions (b) and (c) posit rational and capable capital market investors. In the United States, institutional investors hold over $70 \%$ of the shares of the 1000 largest publicly traded companies (Rabimov and Tonello, 2010, Table 10). We have argued above that assumption (a) - that there are good and bad aspects to PBC acquisition - is plausible. There remains, then, the important assumption- that courts are capable, as a general matter, of distinguishing controlled transactions that use PBC consumption to motivate efficient controller monitoring and other efforts from transactions that are exploitative. As we have stressed, it is centrally this assumption that allows a controlling shareholder to commit to efficient levels of PBC. 
Section 4 discusses this assumption in detail. We note here that generalist courts may have difficulty but specialized courts exist, and more could be created. The Delaware Chancery Court, the new Israeli Corporate court, and the Commercial Part of the New York State Supreme court are examples. These courts are composed of judges with business experience and the cases they see fall into limited and repetitive patterns. This permits the judges to develop expertise (Gilson, Sabel, and Scott, 2013)..$^{18}$

\subsection{The Case for Contract: Judicial Standards and Explicit Agreements}

Were the law to reduce the mandatory rule covering transactions with controlling shareholders to a default that allowed the corporation to specify by explicit contract the standards governing transactions with a controlling shareholder, the controlled corporation (and, implicitly, its minority shareholders) of course could continue to rely upon the standards that compose the current mandatory legal rule. Hence, the contracting reform would not make things worse. Turning to the reform itself, the current legal regime creates considerable uncertainty for controlling shareholders, for two reasons. First, controlling shareholders must predict what the minority shareholders will approve. Second, courts exercise independent review, under the entire fairness standard, of privately approved transactions. Hence, the controlling shareholders must also predict what the courts will approve. Judicial application of a mandatory standard is harder for the controlling shareholder to predict than the preferences of the company's directors or shareholders because generalist courts have less expertise than company officials and may have different normative preferences. In any event, controlled shareholders must incur considerable costs preparing project proposals to the independents, and additional costs defending those proposals in court. The uncertainty that the current two levels of review create - first the minority, then the judge - can chill the pursuit of efficient projects: the likelihood of ultimate approval may be too low to justify the project exploration expense. Express contracts, we argue below, would reduce uncertainty and therefore increase efficiency.

A simple model clarifies these points. Assume again that Delaware law obtains. Let it cost the controlling shareholder $c_{h}$ to explore and present for approval to a committee of independent directors a project that may have high value. It costs $c_{l}$ to explore and present a low-value project. We assume $c_{h}>c_{l}$ because high-value projects are generally harder to find and more complex to evaluate and to explain. The probability that the controlling shareholder locates a high-value project and gets it approved is increasing in his exploration and preparation efforts. A high-value project, if uncovered, returns $v_{h}$; the low-value project returns $v_{l}$. All projects are

18 Gilson, Sabel, and Scott (2013) develop how expert courts like the Delaware Chancery Court can extend the use of standards in the face of uncertainty to police opportunistic behavior with respect to commercial transactions within common categories but which have important idiosyncratic elements that the parties may seek to exploit. 
interested transactions: that is, the controlling shareholder will consume PBC from realized project returns. Denote the probability that investigation reveals a highvalue project as $p\left(c_{h}\right)$ if the controlling shareholder invests $c_{h}$. We assume that (a) low-value projects exist and that $v_{l}-c_{l}>0$ for any such project; and (b) for convenience, that the controlling shareholder can discover a low-value project and get it approved if he invests $c_{l}$ in exploration and presentation cost. The issue is whether the controlling shareholder will attempt to find high-value projects when it is ex ante efficient to do so.

The timing follows:

$t^{0}$ : The controlling shareholder develops a portfolio of possible projects to explore seriously.

$t^{1}$ : The controlling shareholder investigates project possibilities.

$t^{2}$ : The controlling shareholder prepares a report to the independent directors of the project he locates.

$t^{3}$ : The report is presented.

$t^{4}$ : The directors always accept low-value projects but may reject or accept a highvalue project.

$t^{5}$ : A minority shareholder seeks judicial review of an approved high-value project. ${ }^{19}$

$t^{6}$ : The court rejects or accepts.

The probability that the independent directors accept a high-value project is $0 \leq \beta<1$; the probability that a court later accepts an approved high-value project is $0<\lambda<1$. (Regarding these probabilities, we assume that independent directors may reject any high-value project but courts do not reject approved projects with certainty.) Hence, the ex ante probability that the controlling shareholder can pursue a high-value project if he locates one is $\alpha=\beta \lambda<1$.

We begin at $t^{0}$, when the controlling shareholder has a project portfolio and is choosing his investigation level. To identify the first best, let the independent directors and the court accept a high expected value project with certainty. The controlling shareholder then invests high effort if the marginal increase in expected value between the high- and the low-value project exceeds the marginal investigation and presentation cost. Saving some algebra, we write this condition as

$$
p\left(c_{h}\right) \Delta v>\Delta c
$$

where $\Delta v=v_{h}-v_{l}$ and $\Delta c=c_{h}-c_{l}$. The LHS is the marginal value difference; the RHS is the marginal cost difference.

19 PBS consumption, in our view, is best understood as the controlling shareholder taking a share of firm value. This implies that the absolute amount of PBC the shareholder will consume, in absolute dollars, is an increasing function of project value. Low-value projects therefore are less controversial than high-value projects. Independent directors are more likely to accept, and minority shareholders less likely to challenge, low-value projects. To simplify analysis, we assume without loss of generality that minority shareholders never sue to reverse low-value project approvals but always sue to reverse high-value project approvals. 
Now assume, realistically, that a controlling shareholder expects a high-value project to be approved with probability $\alpha$. Then he incurs the high cost to locate a high-value project if

$$
p\left(c_{h}\right) \Delta v>c_{h} / \alpha-c_{l} .
$$

Expression (2) is harder to satisfy than expression (1) because the approval probability $\alpha$ is less than one, so the first term on the RHS exceeds the investigation cost. Intuitively, when approval is uncertain, investigation costs are more likely to be wasted so the controlling shareholder will investigate fewer possibly efficient projects.

To review, section 2 argued that PBC can increase the controlling shareholder's incentive to monitor managers and otherwise to invest effort in implementing projects. Section 3 argues that the current mandatory legal disapproval of PBC acquisition creates considerable uncertainty; controllers must predict the preferences of their own minority and the reviewing court regarding particular controlled transactions. The probability that a controlled transaction will ultimately be approved is materially less than one. A consequence, we show here, is that controlling shareholders are less likely to locate possibly efficient projects to pursue.

Enforceable express contracts are preferable to these implicit contracts initially because they would materially increase the acceptance probability by reducing the likelihood of judicial error. A controlling shareholder would offer a contract to the independent directors at $t^{0}$, after he has assembled a portfolio of potential projects but before he investigates. The contract likely would disclose possible projects the controller would pursue and propose associated PBC consumption levels. Bargaining thus would take place, and a contract would be accepted, before the investigation stage. Because the independent directors would then have signed on, the controlling shareholder would anticipate independent director approval of any high-expected-value project that he proposes. Using the notation above, the probability of independent party acceptance, $\beta$, would be one.

Courts also would be more likely to enforce than they are today because such explicit contracts, under our proposal, would be enforceable. Thus, the likelihood of judicial approval, $\lambda$, would rise as well. Additionally, an explicit contract, tailored to particular transactions and parties, would reduce the likelihood of judicial error even by a generalist court. As the joint acceptance probability, $\alpha$, increases toward one, expression (2) collapses to expression (1). Free contracting would expand the set of efficient projects controlled companies would pursue. We assume that the controlling shareholder will not propose to the independent directors a lowvalue project but claim that the project has high expected value. The shareholder must disclose the nature of the project and the share of $\mathrm{PBC}$ he will consume. For example, the project may contemplate sales between corporate entities, both of which the shareholder controls, at particular prices. The shareholder is more likely to get a project approved by understating its profit potential than overstating it: to understate is to appear to take fewer PBC as a share of project returns. Note that 
this reasoning underscores the importance of independent directors even where the controlling shareholder controls their election.

Express contracting also would reduce transaction costs. Under current law, the likelihood that courts uphold independent director approval of interested transactions is increasing in the size and apparent thoroughness of the record a controlling shareholder makes to the directors. In the courts' view, the more complete the controlling shareholder's disclosure is, the better informed the independent parties are and the more likely the transaction is to be in the company's interest. Controlling shareholders, when choosing investigation levels, thus know that the total cost of obtaining acceptance of a high-value project, which includes presentation cost, is high. Referring to the model above, the courts' attitude widens the wedge between the cost of exploring possible high-value projects, $c_{h}$, and the cost of pursuing lowvalue projects, $c_{l}$. As both expressions show, when this wedge widens, controlling shareholders are less likely to locate high-value projects. A contract reduces the cost of assembling a record that must pass both independent director and judicial scrutiny. In this way as well, allowing explicit contracting over PBC would increase the set of efficient projects that controlled companies pursue.

Under a default rule approach, most lawsuits could be expected to involve moral hazard. The common issue would be whether the controlling shareholder exceeded a contractual cap: that is, seized more PBC than bargained for. Actions over PBC consumption thus may raise interpretive issues concerning even an explicit contract, although they may be of lesser burden than under a standard-based mandatory regime.

To summarize, current ex post judicial review under a mandatory standard requires that courts determine whether the PBC consumption associated with a particular interested transaction is within the zone of reasonableness. In a default rule world, courts would police contracts for procedural fairness and interpret the substantive terms they contain, which may in some circumstances take a form similar to a zone of reasonableness standard, and in others may be more precisely tailored to the context of the particular company or transactions. A high level of expertise improves judicial performance of both tasks, the issue to which we now turn.

\section{The Centrality of Courts: A Proposal for Improving Ex Post Judicial Review of PBC Consumption}

\subsection{The Need for a Standard}

We have stressed that the argument in favor of ex post judicial review assumes that judicial systems are effective and staffed with judges who are experienced in complex commercial law, regardless of whether the court applies a mandatory legal standard or an explicit contract adopted under a default rule approach. The first step in the analysis is straightforward - parties must anticipate that the judicial system will adjudicate private challenges to particular levels of PBC consumption within a commercially reasonable period of time. As Professors Ferrarini and Giudici have 
stressed with respect to the PBC at the heart of the Parmalat scandal, substantive legal rules are irrelevant absent timely and effective enforcement. The second step - of the critical role of judicial expertise - requires more detailed development. Our discussion here parallels the discussion above. We first consider the relevance of expertise when courts apply a mandatory standard to a transaction. We then consider how expertise manifests when courts adjudicate explicit contracts that regulate PBC under a default rule approach. This sets the stage for our policy proposal.

There is a general view that courts should regulate business behavior by reference to standards of conduct rather than specific rules. The argument roughly parallels the move from state contingent contracting to the use of standards as uncertainty increases (Gilson, Sabel, and Scott, 2012). A rule is most effective when there are few relevant states of the world and the mapping from actions to states is clear that is, when there is little uncertainty. Given these conditions, the court can apply, in effect, a state contingent rule that proscribes or requires clearly specified actions, and can readily determine whether the rule has been followed. These conditions that make rules effective sometimes are satisfied for typical sales transactions, but they are much harder to satisfy at the level of managing a company. ${ }^{20}$ Business contexts evolve rapidly so uncertainty is high, and can be expected to be particularly high in settings where the heightened monitoring and managerial skills of controlling shareholders are important. The more the corporation's current value depends on future growth options as to which management's judgment is important and therefore the greater the uncertainty, the less workable are rules as opposed to standards; the very point of a standard is to allow for the judgment that a rule excludes. Further, the efficient mix of PBC consumption and efficient managing can be expected to be context-specific. For these reasons, rules can be over- or under-inclusive.

The case for a regulatory standard then is straightforward: when uncertainty prevents legislatures (or courts) from imposing state contingent rules, striking the appropriate balance between the costs and benefits of particular transactions requires standards. ${ }^{21}$ Under a standard, whether a particular transaction is reasonable is decided ex post. The passage of time and the parties' performance often resolves uncertainty about the effect of transactions. A court thus can make an informed judgment regarding a litigated transaction's reasonableness.

But the relationship between uncertainty and the effectiveness of standards is not monotonic (Gilson, Sabel, and Scott, 2012). The cost of judicial application of standards is the risk the judge in applying the standard to particular facts will make type-one and type-two errors. Parties anticipate the possibility of error when deciding how to craft their relationship in the first place. If the law imposes a standard, and the error probability is large, parties then may use rules in their contracts despite the risk that under high uncertainty the rules will turn out to be wrong ex post. Indeed, the possibility that the judge (or jury) will make an error can lead to moral-hazard-based

20 An extensive analysis of when rules or standards are better contractual regulatory devices is in Schwartz and Scott (2003).

21 Recall that the regulatory task is to preserve the efficiency gains from better monitoring that PBC induces while curbing their excessive use. 
litigation (the party disfavored by fate litigating in the hope of winning the judicialerror lottery). Legislatures also may respond to the uncertainty standards can create by adopting knowingly inefficient prohibitions (Gilson, Sabel, and Scott, 2013).

\subsection{Contracts and Judicial Expertise}

We assume in this section that legal restrictions on PBC take the form of defaults, so that parties can write express joint $\mathrm{PBC} /$ project contracts if they fit the parties and transaction better than the default legal standard. We expect these contracts to contain a mix of express terms and standards - in essence, to set out the context in which the controlling shareholder and the company are dealing and that of the transaction. The express terms will describe possible or actual projects and the nature of PBC consumption under them. For example, a lower firm in a pyramid will invest in a project and plan to trade with the market and with another firm in which the controlling shareholder has an interest. He will consume PBC in connection with the interested party trades. Depending on the circumstances, the contracts also may attempt to cap PBC through rule-like provisions, for example in the form of regulating the prices of interested party trades, perhaps through the use of a pricing formula (as often used in long-term supply contracts). Finally, because there is uncertainty in project pursuit, and moral hazard in the form of the controlling shareholder's incentive to exceed a cap and in minority shareholder litigation over the cap, we expect the contracts likely will require standards as well that will bear some resemblance to the entire fairness standard: controlling shareholders will commit to confine PBC consumption to "reasonable" levels and provide guidance for the court's interpretation of "reasonableness" in the context of the category of interested transactions covered by the contract. ${ }^{22}$

Judicial expertise as described above consists of the ability to evaluate particular transactions, which can be characterized as composed of four general forms: (i) expertise in interpreting contractual language; (ii) expertise in evaluating evidence, especially trial evidence; (iii) expertise in inferring ex ante intended performances from actually rendered performances; and (iv) experience with the industry and with the types of transactions that come before the court. ${ }^{23}$ Courts in developed countries possess the first two types of expertise. They are trained to read contracts and to conduct trials, and they commonly do both. The third type of expertise is less common and generalist courts typically will not have the fourth. The presence of the third and fourth types of expertise operates to make the first two types more effective.

As an example of type (iii) expertise, consider a contract dispute. The buyer rejects a machine because, he claims, it was supposed to perform a certain number of

22 This description is speculative. Current law precludes express contracts except in limited circumstances (see Delaware General Corporation Law, 8 Del., § 122(17), 2012), so there are no actual models. We claim only plausibility here. We note also that the standards will not permit unconfined judicial behavior. The writing evidences the permitted and the standard includes difficult to predict applications.

23 This taxonomy is explained and applied in Schwartz and Watson (2013). 
operations a minute, and it performs many fewer. The seller agrees that the machine performs fewer operations than the buyer claims was intended, but argues that the parties intended only the actual performance the machine is capable of rendering. Suppose also that machines that perform the larger number of operations have a particular configuration that the machine at issue lacks; rather, the machine involved in the litigation is configured such that producing a materially higher number of operations than it performs would create undue stress. An expert adjudicator, such as an arbitrator who has experience in the industry, would understand machine types, and so would promptly recognize that the parties likely intended to trade the machine the seller tendered. He would then order the buyer to pay unless the buyer could disprove the adjudicator's plausible inference of the parties' ex ante intentions. An inexpert generalist court, that did not have industry experience, may require a trial to decide the case, and even then may be mistaken.

Interpreting the $\mathrm{PBC} /$ project contracts described above requires similar expertise and experience. To see why, consider the pyramid example above. Let there be an optimal mix of market and interested trades for the product the controlled firm produces. An objecting shareholder sues the controlling shareholder, claiming that although the interested trades were made at contractually set prices, which were known to be above market, there were too many interested trades. The controlling shareholder imposed these trades, it is argued, as a device to exceed the PBC contractual cap; that is, actual PBC consumption violated the contract's standard.

An adjudicator who possesses the third and fourth types of expertise, in inferring intentions from performances and with industry and transactional experience that facilitates that inference, is more likely than a generalist court to decide this type of dispute correctly. The expert adjudicator would have some industry knowledge, he would see many interested transactions and he would understand the strengths and temptations that the separation of cash flow and control rights make possible. The expert thus would have some rough idea, in connection with a PBC consumption dispute, what mix of market and interested trades would be optimal and whether it was materially exceeded in the case before him. Put differently, an experienced, expert court understands the context in which the contract over PBC extraction must be interpreted (Schwartz and Watson, 2013; Gilson, Sabel, and Scott, 2013). A generalist court would be much harder to inform and, once informed, would be more likely to make an error, the probability of which is increasing in the level of uncertainty.

As is apparent, the expertise of reviewing courts becomes central both to our argument that ex post judicial review under standards is preferable to ex ante structural reform, and to our argument that free contracting may be best of all. It is the capacity of experienced commercial courts to apply standards even as uncertainty increases that provides the basis for our proposal here. Whether applying mandatory fiduciary duties or interpreting contractual terms and especially contractual standards adopted in response to uncertainty, sophisticated commercial courts, coupled with timely enforcement, allow controlling shareholders to credibly commit to a level of PBC that can support efficient controlling shareholder corporate structures. As we have seen, 
this expert ex post review is superior to rule-like prohibitions of leveraged control structures or more general restrictions on the prevalence of controlling shareholder structures like a mandatory bid rule.

But the promise of efficient PBC consumption that increases minority shareholders' investment by more than the PBC cost is a chimera to a corporation that is chartered in a jurisdiction without an effective, experienced judicial system; absent expertise, standards are workable over a narrower range of uncertainty, so the efficient outcome is not feasible (Gilson, Sabel, and Scott, 2013). For these jurisdictions, the logical response is to rely more heavily on ex ante structural restrictions and on rule-like constraints, with the result that corporations are denied access to control structures that may be efficient in particular circumstances. And it is correct but of limited value to recommend that the jurisdiction develop an effective judicial system. Crafting the institutions and norms that support an effective judicial system takes substantial time (Dammann and Hansmann, 2008); in the meantime, companies incorporated in that jurisdiction, predictably with a high likelihood of a controlling shareholder, will continue to pay a higher cost of capital because of the absence of a way to commit credibly to a level of PBC.

A better alternative to waiting for domestic institutions to evolve would be for the European Union to facilitate controlling shareholders' credible commitment to limit PBC by creating an EU-level-specialized commercial court that could manage the use of standards under high uncertainty. This is particularly important because it is in precisely those "bad law" countries that the Law and Finance literature tells us we are most likely to have economies dominated by companies with controlling shareholders. Thus, an EU-level commercial court takes advantage of scale economies in judicial reform in just the settings where the payoff to expertise is the greatest. Individual corporations could elect through their articles of incorporation to have interested transactions reviewed by the EU commercial court rather than the courts of the jurisdiction under whose laws the corporation is formed. ${ }^{24}$ In our vision, the EU court would apply the law of the state of incorporation, but with greater speed and expertise, and therefore lower error rates in the face of uncertainty, than could be mustered in the home state. When this condition is not met, the corporation would remain under the jurisdiction of domestic courts. In this respect, our proposal differs greatly from the thrust of prior EU efforts to address corporate law. Unlike the variety of EU company law directives, the creation of an EU commercial court would not impose mandatory rules that harmonize substantive corporate law; individual corporations would have to opt into its jurisdiction. ${ }^{25}$ And unlike the European Company Law, the corporation that opts in accepts an enforcement process, not a body of substantive law.

24 The expertise and efficiency of the Delaware Chancery Court, rather than any special character of Delaware law, is in our view the best explanation for the persistent preference for U.S. public corporations to incorporate in Delaware (Gilson, Sabel, and Scott, 2013).

25 Elements of the Thirteenth Directive on Takeovers has this opt-in like characteristics. However, the 13th Directive is nonetheless directed at substantive law. 
To be sure, we recognize that there are important jurisprudential issues that would have to be addressed in the actual design of a European commercial court, and serious political problems that would have to be overcome for the effort to be successful. For example, a federalist system with two levels of courts confronts a range of vertical - federal law versus (member) state law - choice of law issues (as opposed to horizontal issues concerning which member state's law applies). In the United States, the resolution has taken the form of having a federal court adjudicating a state substantive law issue apply federal procedural rules but state substantive law. So for example, an EU-level commercial court might adopt its own rules concerning class actions, but be bound by member-state rules on who could bring derivative suits. Thus, the determination of the corporate law techniques available for enforcement remains at the member-state level. ${ }^{26}$ Only the skill of the court changes.

A careful consideration of these issues is beyond our ambition here and likely our ken as well. But recognizing these concerns, an opt-in European court gives all European corporations the capacity for credible commitment that allows access to efficient control structures regardless of the varied quality of judicial systems across the EU. Of equal significance, it will have the greatest impact where the absence of an effective judicial system imposes the highest cost of capital penalty on the presence of a controlling shareholder.

\section{Conclusion}

In this paper, we analyze a continuum of approaches to constraining private benefits of control: ex ante structural restrictions on control and ex post transaction review. Regulation of controlling shareholders in the European Union includes significant ex ante structural restrictions. Because of the fear of PBC, the EU directly regulates companies' control structures and shareholder distribution patterns. EU member states frequently prohibit the use of dual-class common stock; and EU law leans against controlling shareholder regimes generally through the directive-level mandatory bid rule. This strategy of ex ante control mechanisms is premised on the fear that controlling shareholders will take too much PBC - that is, an amount that is greater than the minority shareholders' gain from the controlling shareholder's better monitoring. In contrast, regulation of controlling shareholders in the United States leans in the other direction. Rather than ex ante structural restrictions on control structures, the leading U.S. jurisdiction - Delaware - imposes a legal rule that subjects transactions with controlling shareholders or their affiliates to ex post "entire fairness" review by an expert court, which is interpreted to mean that the terms of a transaction must be within a range of reasonableness in relation to market prices. Contingent on intelligent enforcement by sophisticated commercial courts, ex post judicial review has a number of useful benefits, all of which are improvements over the ex ante prohibitions of leveraged control structures or, more

26 These rules vary significantly among member states (see Enriques, 2000, and Conac, Enriques, and Gelter, 2007). 
generally, that restrict the emergence of controlling shareholder regimes through the mandatory bid rule, that we observe in the EU.

These benefits are as follows. First, ex post transactional review allows control structures that have the potential to provide better monitoring and hence better performance than a B\&M-style company. Second, by capping the amount of PBC through effective judicial review, the lemons problem of companies having to pay through the cost of capital for excessive PBC is avoided. Companies could make credible commitments to efficient levels of $\mathrm{PBC}$. Third, by allowing some range of $\mathrm{PBC}$ - the "in the range of reasonableness" measure - corporations can secure the benefits of a controlling shareholder's more effective monitoring when it is efficient. This allows the determination of control structures to be endogenized. We also argue that treating an entire fairness-like standard as a default, rather than as mandatory, probably could achieve these benefits at least as well, and perhaps better, than mandatory legal standards.

The next step in our analysis is that central to the U.S. approach - generally allowing leveraged control structures and not penalizing controlling shareholders - is the existence of efficient and sophisticated courts to apply legal standards and interpret contracts. The centrality of judicial expertise to ex post regulation leads to our reform proposal. As Ferrarini and Giudici observe with respect to Italy, the problem is not so much the substantive legal rules, as much as it is the absence of an efficient, experienced court system and, to be sure, corporate law that allows claims to be brought. In this situation, a company cannot credibly commit not to consume PBC in excess of the gains from better monitoring. The cost of capital then goes up regardless of a company's intention to limit levels of PBC consumption. Under those circumstances, it is understandable that some member states prohibit leveraged control structures.

We offer an alternative: an effective judicial system that allows sophisticated judicial application of standards. The EU could achieve such a system by creating a European Commercial Court, to whose jurisdiction a corporation may opt in. Unlike the European Company statute, it is process rather than substantive law that is voluntarily harmonized; the applicable substantive law remains that of the state of incorporation. Less modestly, we argue that the same specialized court can support a more expansive reform: making legal rules concerning review of interested transactions a default, which the corporation can change by contract. In both the modest and expansive reform, the insight is that ex post review of interested transactions rather than ex ante leaning against particular forms of control structures allows controlling shareholders to credibly commit to efficient levels of PBC.

\section{References}

The American Law Institute (1994), Principles of Corporate Governance and Structure: Restatement and Recommendations, American Law Institute Publishers, Philadelphia (PA).

Atanasov, V., B. Black, and C. S. Ciccotello (2011), "Law and Tunneling," The Journal of Corporation Law, 37(1), 1-49. 
Berle, A. A., and G. C. Means (1932), The Modern Corporation and Private Property, Macmillian Co., New York.

Claessens, S., S. Djankov, J. P. H. Fan, and L. H. P. Lang (2002), "Disentangling the Incentive and Entrenchment Effects of Large Shareholdings," The Journal of Finance, 57(6), 24712771.

Conac, P.-H., L. Enriques, and M. Gelter (2007), "Constraining Dominant Shareholders' Self-Dealing: The Legal Framework in France, Germany, and Italy," European Company and Financial Law Review (ECFR), 4(4), 491-528.

The Council of the European Union (2001a), "Council Regulation (EC) No. 2157/2001 of 8 October 2001 on the Statute for a European Company (SE)," Official Journal of the European Communities, L 294, 1-21.

- (2001b), "Council Directive 2001/86/EC of 8 October 2001 Supplementing the Statute for a European Company with Regard to the Involvement of Employees," Official Journal of the European Communities, L 294, 22-32.

Dammann, J. (2008), “Corporate Ostracism: Freezing Out Controlling Shareholders," Journal of Corporation Law, 33(3), 683-744.

— and H. Hansmann (2008), "Globalizing Commercial Litigation," Cornell Law Review, 94(1), 1-72.

Dyck, A., and L. Zingales (2004), "Private Benefits of Control: An International Comparison," The Journal of Finance, 59(2), 537-600.

Enriques, L. (2000), "The Law on Company Directors' Self-Dealing: A Comparative Analysis," International and Comparative Corporate Law Journal, 3(3), 297-333.

The European Parliament and the Council of the European Union (2004), "Directive 2004/25/EC of the European Parliament and of the Council of 21 April 2004 on Takeover Bids," Official Journal of the European Union, 142, 12-23, http://eur-lex.europa.eu/ LexUriServ/LexUriServ.do?uri=OJ:L:2004:142:0012:0023:EN:PDF.

Ferrarini, G., and P. Giudici (2006), "Financial Scandals and the Role of Private Enforcement: The Parmalat Case," in: J. Armour and J. A. McCahery (eds.), After Enron: Improving Corporate Law and Modernising Securities Regulation in Europe and the US, Hart Publishing, Oxford, pp. 159-214.

Gilson, R. J. (2006), "Controlling Shareholders and Corporate Governance: Complicating the Comparative Taxonomy," Harvard Law Review, 119(6), 1641-1679.

- (2007), "Controlling Family Shareholders in Developing Countries: Anchoring Relational Exchange," Stanford Law Review, 60(2), 633-656.

— and J. N. Gordon (2003), "Controlling Controlling Shareholders," University of Pennsylvania Law Review, 152(2), 785-843.

- C. F. Sabel, and R. E. Scott (2012), "Text and Context: An Integrated Theory of Contract Interpretation," Working Paper, Columbia Law School, New York.

—, - , and - (2013), "Contract and Innovation: The Limited Role of Generalist Courts," New York University Law Review, 87, forthcoming.

— and A. Schwartz (2012), "Contracting about Private Benefits of Control," Working Paper, Yale Law School, New Haven (CT).

Gompers, P. A., J. Ishii, and A. Metrick (2010), "Extreme Governance: An Analysis of DualClass Firms in the United States," The Review of Financial Studies, 23(3), 1051-1088.

Institutional Shareholder Services, Shearman \& Sterling, and the European Corporate Governance Institute (2007), "Report on the Proportionality Principle in the European Union," Brussels, Belgium, http://ec.europa.eu/internal_market/company/docs/shaeholders/study/ final_report_en.pdf, last visited August 22, 2012.

Jensen, M. C., and W. H. Meckling (1976), "Theory of the Firm: Managerial Behavior, Agency Costs and Ownership Structure," Journal of Financial Economics, 3(4), 305360.

La Porta, R., F. Lopez-de-Silanes, A. Shleifer, and R. W. Vishny (1998), "Law and Finance,” Journal of Polititcal Economy, 106(6), 1113-1155. 
Mahoney, P. G. (2012), “The Public Utility Pyramids,” The Journal of Legal Studies, 41(1), 37-66.

Nenova, T. (2003), “The Value of Corporate Voting Rights and Control: A Cross-Country Analysis," Journal of Financial Economics, 68(3), 325-351.

Rabimov, S., and M. Tonello (2010), "The 2010 Institutional Investment Report: Trends in Asset Allocation and Portfolio Composition," The Conference Board of Canada, Ottawa.

Schwartz, A., and R. E. Scott (2003), "Contract Theory and the Limits of Contract Law," The Yale Law Journal, 113(3), 541-620.

- and J. Watson (2013), "Conceptualizing Contract Interpretation," The Journal of Legal Studies, 42(2), forthcoming.

Ronald J. Gilson

Charles J. Meyers Professor

of Law and Business

Stanford Law School

Stanford, CA 94305

U.S.A.

rgilson@stanford.edu

\author{
Alan Schwartz \\ Sterling Professor of Law \\ Yale Law School \\ P.O. Box 208215 \\ New Haven, CT 06520 \\ U.S.A. \\ alan.schwartz@yale.edu
}

